\title{
Effects of Species Proportions and Fertility on Sedum Green Roof Modules
}

\author{
Kristoffer J. Barker ${ }^{1}$ and Jessica D. Lubell ${ }^{2,3}$
}

ADDITIONAL INDEX WORDS. controlled-release fertilizer, digital image analysis, living roof, Sedum, vegetated roof

Summary. Nursery producers are interested in supplying sedum (Sedum sp.)vegetated modular units for the green roof industry. This research examined the influence of three rates of controlled-release fertilizer (CRF) $(50,78$, and $108 \mathrm{~g}$ per unit of $15 \mathrm{~N}-3.9 \mathrm{P}-10 \mathrm{~K}, 8$ - to 9 -month formulation) on production of modules containing one or two Sedum species. Six Sedum species were evaluated independently: 'Angelina' sedum (Sedum rupestre), gray sedum (S. pachyclados), 'John Creech' sedum (S. spurium), tasteless sedum (S. sexangulare), 'Weihenstephaner's Gold' sedum (S. kamtschaticum var. floriferum), and white sedum (S. album). The species were then paired as follows: white sedum/'John Creech' sedum, 'Weihenstephaner's Gold' sedum/'Angelina' sedum, and gray sedum/tasteless sedum. For each pair, three starting proportions of cuttings were studied. In 8 weeks, the medium and high fertility rates produced significantly more units with at least $95 \%$ vegetation coverage than the low rate. In general, increasing the fertility rate increased the fresh weight at time of harvest, except for 'Weihenstephaner's Gold' sedum and tasteless sedum at the high rate, which developed "melt out." Melted-out tissues turned brown, desiccated and detracted from the visual appearance of units. 'John Creech' sedum and white sedum had the greatest fresh weight followed by 'Weihenstephaner's Gold' sedum, 'Angelina' sedum, and tasteless sedum. Gray sedum grew substantially slower than all other species and had the lowest fresh weight. For white sedum/'John Creech' sedum units, harvest fresh weight proportions were similar to starting cutting fresh weight proportions. For gray sedum/tasteless sedum units, tasteless sedum outgrew gray sedum and gray sedum was barely noticeable in finished units. Harvest fresh weight and digital image analysis (DIA) of 'Weihenstephaner's Gold' sedum/'Angelina' sedum units indicated that 'Weihenstephaner's Gold' sedum colonized units faster than

'Angelina' sedum, and had greater visual impact in finished units. Units started with $\mathbf{2 5 \%}$ 'Weihenstephaner's Gold' sedum cuttings, the smallest proportion tested, were roughly $73 \%$ covered with 'Weihenstephaner's Gold' sedum at harvest. We recommend growers use the medium fertility rate to produce the most units with 95\% vegetation or more in the least amount of time and with reduced risk of melt out. To achieve desired final species proportions, growers may need to adjust the ratios of cuttings based on uneven species vigor.

$\mathrm{T}$ The use of modular green roof systems is increasing due to their ease of delivery and installation and immediate rooftop aesthetic value. In a modular green roof system, the vegetation and planting media are contained within specialized trays (Wark and Wark, 2003) that vary in size but do not exceed 6 inches in depth (Snodgrass and Snodgrass, 2006). Sedum species and cultivars are often grown on modular green roofs because they tolerate shallow substrates (Durhman et al., 2007; Emilsson,

Department of Plant Science and Landscape Architecture, University of Connecticut, 1376 Storrs Road, Unit 4067, Storrs, CT 06279-4067

${ }^{1}$ Graduate Research Assistant

${ }^{2}$ Assistant Professor

${ }^{3}$ Corresponding author. E-mail: jessica.lubell@uconn. edu
2008) and adverse rooftop conditions of drought (Durhman et al., 2006; Wolf and Lundholm, 2008), high heat, direct sunlight, wind, and snow load (Getter and Rowe, 2006). Green roof modules that are fully vegetated need only to be set in place at the time of installation.

Nursery producers are beginning to supply vegetated modules for the expanding green roof industry. Green roof module production differs from typical container production in the planting medium used. The planting medium is typically composed of $75 \%$ to $90 \%$ inorganic materials such as expanded slate, clay or shale, perlite, or scoria that do not break down rapidly over time (Beattie and Berghage, 2004). The remainder of the substrate is composed of organic matter such as peat, bark, or compost.

Currently, modules are grown using sedum plugs or cuttings that are distributed on the surface. Most producers use a blend of five to eight Sedum species or cultivars per module at a rate of $0.4 \mathrm{lb}$ of cuttings per module [LiveRoof ${ }^{\circledR}$ Licensed Grower (LiveRoof, Spring Lake, MI), personal communication]. There is also a demand for modules containing only one or a few species of a similar color palette for use in creating color block designs or patterns on the green roof. It requires 10 to 12 weeks to produce a marketable sedum-vegetated module with $95 \%$ vegetation coverage started from cuttings (LiveRoof $\AA$ Licensed Grower, personal communication). Appropriate fertility programs to grow these modules quickly and effectively would benefit nursery producers interested in providing modules for the green roof industry.

Few studies have examined appropriate fertility rates for producing sedum-vegetated green roof modules (Emilsson et al., 2007). During a 3 -year study, Rowe et al. (2006) evaluated the growth of the sedum cultivars 'Diffusum' and 'Royal Pink' in modules treated each spring with four levels $\left(0,50,100\right.$, and $\left.150 \mathrm{~g} \cdot \mathrm{m}^{-2}\right)$ of $13 \mathrm{~N}-5.7 \mathrm{P}-10.8 \mathrm{~K}$ CRF (Nutricote ${ }^{\mathrm{TM}}$ Type 180, 6-month formulation; Plantco, Brampton, ON, Canada). By the end of the first year, which may be considered a production year, both sedum cultivars achieved greater growth when treated with 100 and $150 \mathrm{~g} \cdot \mathrm{m}^{-2}$ of fertilizer. The objective of this study was to determine the fertility rates

\begin{tabular}{llll}
\hline $\begin{array}{l}\text { Units } \\
\text { To convert U.S. to SI, } \\
\text { multiply by }\end{array}$ & U.S. unit & SI unit & $\begin{array}{l}\text { To convert SI to U.S., } \\
\text { multiply by }\end{array}$ \\
\hline 0.3048 & $\mathrm{ft}$ & $\mathrm{m}$ & 3.2808 \\
3.7854 & $\mathrm{gal}$ & $\mathrm{L}$ & 0.2642 \\
2.54 & inch(es) & $\mathrm{cm}$ & 0.3937 \\
0.4536 & $\mathrm{lb}$ & $\mathrm{kg}$ & 2.2046 \\
28.3495 & $\mathrm{oz}$ & $\mathrm{g}$ & 0.0353 \\
33.9057 & $\mathrm{oz} / \mathrm{yard}^{2}$ & $\mathrm{~g} \cdot \mathrm{m}^{-2}$ & 0.0295 \\
$\left({ }^{\circ} \mathrm{F}-32\right) \div 1.8$ & ${ }^{\circ} \mathrm{F}$ & ${ }^{\circ} \mathrm{C}$ & $\left(1.8 \times{ }^{\circ} \mathrm{C}\right)+32$
\end{tabular}


required to produce high-quality modules in the shortest time possible using popular Sedum species: 'Angelina' sedum, gray sedum, 'John Creech' sedum, tasteless sedum, 'Weihenstephaner's Gold' sedum, and white sedum.

\section{Materials and methods}

Experimental Design. This experiment was conducted in an outdoor container growing area at the University of Connecticut Plant Science Research Facility in Storrs (lat. $41.795768^{\circ} \mathrm{N}$, long. $\left.72.227876^{\circ} \mathrm{W}\right)$. The experiment used three CRF rates and 15 Sedum species combinations arranged in a split plot design with five replications. The main plot was fertility rate and the subplot was species combination. LiveRoof $\AA$ standard size $(24 \times 12 \times 4$ inches $)$ green roof modules and LiveRoof $®$ growing medium were used. The growing medium contained $15 \%$ organic matter and $60 \%$ solite and had $45 \%$ porosity. Modules were divided into half using a section of LiveRoof $\AA$ Deep Soil Elevator ${ }^{\mathrm{TM}}$ measuring $12 \times 6 \times$ 0.25 inches inserted into the media at the center of each module, and each half module constituted a subplot or experimental unit. The split plot arrangement allowed for both halves of a single module to receive the same fertility rate. Totally 120 modules were used. Controlled-release $15 \mathrm{~N}-$ 3.9P-10K fertilizer (Osmocote $\AA$ Plus, 8- to 9-month formulation; Scotts, Marysville, $\mathrm{OH}$ ) was applied at 50, 78, and $108 \mathrm{~g}$ per unit. An 8- to 9-month formulation was chosen because this formulation is typical for container production in Connecticut, and when the units are sold they will have continued fertility for the first year. The fertility rates used in this study were based on the product label. A zero control was not included because preliminary studies indicated that growth was inadequate without some fertility level since the media is largely inorganic (data not shown). In the preliminary study, the zero control application produced only 30\% cover. This experiment was first conducted in 2010, and was repeated in 2011.

Plant material. Each subplot received $0.2 \mathrm{lb}$ of sedum cuttings. Cuttings, ranging from 2 to 3 inches long, of 'Angelina' sedum, gray sedum, 'John Creech' sedum, tasteless sedum, 'Weihenstephaner's Gold' sedum, and white sedum were obtained from Prides Corner Farms (Lebanon, CT). The six species were evaluated independently and in pairs as follows: white sedum and 'John Creech' sedum, gray sedum and tasteless sedum, and 'Weihenstephaner's Gold' sedum and 'Angelina' sedum. The pairings were chosen based on the plants' habit, and allowed us to evaluate two creeping types grown together, one creeping and one upright type, and one creeping and one rosetteforming type. For each pair, three combinations were derived: $0.05 \mathrm{lb}$ $(25 \%)$ sedum $1+0.15 \mathrm{lb}(75 \%)$ sedum $2,0.1 \mathrm{lb}(50 \%)$ sedum $1+0.1 \mathrm{lb}(50 \%)$ sedum 2 , and $0.15 \mathrm{lb}(75 \%)$ sedum $1+$ $0.05 \mathrm{lb}(25 \%)$ sedum 2. Cuttings were distributed on the surface of filled modules on 20 May of both years. Immediately after distributing, modules were covered with $47 \%$ woven shadecloth to facilitate rooting. After $21 \mathrm{~d}$, when most of the cuttings had rooted, the shadecloth was removed and fertility treatments were applied by topdressing. Modules were provided $30 \mathrm{~min}$ of overhead sprinkler irrigation every day for the first $36 \mathrm{~d}$ of the study and each half module received $\approx 0.7 \mathrm{~L}$ of water per day. After day 36, when cuttings were fully established, the irrigation was reduced to every other day at the same daily rate.

Data COllection. In nursery production modules are considered ready for sale when $95 \%$ or more of the surface of the media is covered with vegetation and vegetation coverage is determined by visual observation (LiveRoof ${ }^{\circledR}$ Licensed Grower, personal communication). On days 42 (week 6), 49 (week 7), and 56 (week 8 ) of the study, the number of half modules with $95 \%$ or more vegetation coverage was counted. Half modules were considered $95 \%$ or more vegetated if no media was visible or only minimal media was visible at the edges of the unit. DIA was conducted for 'Weihenstephaner's Gold' sedum/'Angelina' sedum units on day 56 of the study in 2011 only. The process of DIA required taking digital images and then determining plant cover using image analysis software. The dark green foliage of 'Weihenstephaner's Gold' sedum and the vibrant yellow foliage of 'Angelina' sedum easily could be distinguished using DIA software. DIA was not conducted for the combinations white sedum/'John Creech' sedum and gray sedum/tasteless sedum because the foliage colors of each pair could not be distinguished using the software. Images were taken using a digital camera (Powershot G7 with $6 \times$ optical zoom 10.0 megapixel lens; Canon, Lake Success, NY) that was mounted on the top of a $2 \times 2 \times 2$-ft light box. The light box was fitted with four selfballasted 9-W compact fluorescent bulbs. Images were downloaded from the camera as $640 \times 480$ pixels and saved in 24-bitmap format. DIA was performed on images using Sigma Scan Pro 5.0 (Systat Software, San Jose, CA) image analysis software to yield plant cover. Each experimental unit was individually evaluated after the image was cropped to remove the adjacent unit. The percent of total digital pixels represented by 'Angelina' sedum was measured using hue values of 40 to 60 and saturation values of 40 to 100 . Plant harvest began on day 56 of the study and lasted for $4 \mathrm{~d}$ in both years. Plant harvest was accomplished by removing with pruning shears all of the aboveground vegetation. Fresh weight was recorded and for multiple sedum subplots plant material was first sorted by species and then weighed.

STATISTICAL ANALYSIS. SAS (version 9.1; SAS Institute, Cary, NC) software was used for statistical analysis. Analysis of variance using the PROC MIXED procedure was performed for the dependent variables fresh weight and percent cover. There was no significant difference between years, so the data from both years were combined for statistical analysis. For the variable fresh weight, sedum main effect was significant but fertility main effect and the interaction were not significant. For the variable percent cover, the interaction was significant. Differences were separated using Fisher's least significant difference test. Chi-square tests were performed on combination sedum data to determine whether the final sedum proportions were different from the starting proportions. Differences between fertility rates within day for the dependent variable percent of units with at least $95 \%$ vegetation coverage were determined using multiple comparisons for proportions and Tukey's test (Williams and LeBlanc, 1995 ). 


\section{Results and discussion}

The medium and high fertility rates resulted in more units with at least $95 \%$ vegetation coverage in less time (Fig. 1). As early as day 42 of the study, the high rate produced more than four times as many units with at least $95 \%$ vegetation coverage in comparison with the low rate. Using the high fertility rate, growers can expect optimally $26 \%$ of units to have at least $95 \%$ vegetation coverage and be ready for sale by day 42 . By day 49 , the percentage had more than doubled to $56 \%$. By day 56, growers can expect up to $80 \%$ of units to have at least $95 \%$ vegetation coverage using the medium or high fertility rate. This is significantly greater than the $66 \%$ growers can expect using the low fertility rate.

The high and medium fertility rates were not statistically different at any of the three timings (Fig. 1). The percent of units with at least $95 \%$ vegetation coverage for the high rate dropped slightly below the medium rate at day 56, possibly due to withering or "melting out" of tasteless sedum and white sedum. During periods of warm weather in July, we observed some melting out on units receiving the high fertility rate. Meltedout tissues turned brown, desiccated and detracted from the visual appearance of modular units. In July 2010 and 2011, there were 9 and $8 \mathrm{~d}$, respectively, when the temperature was at or above $85^{\circ} \mathrm{F}$ in Connecticut. LiveRoof ${ }^{\circ}$ Licensed Growers in Connecticut also experienced melting-out symptoms for these species during these notably warm periods of July. It has been found that fertilization can make plant tissue more succulent and less resilient (Jauch, 1993; Nagase and Dunnett, 2011; Rowe et al., 2006), which may explain the increased incidence of melt out observed at the highest fertility rate.

'John Creech' sedum produced the greatest fresh weight followed by white sedum (Table 1). 'Angelina' sedum, 'Weihenstephaner's Gold' sedum, and tasteless sedum produced moderate fresh weights and gray sedum produced the lowest fresh weight. Other investigators found white sedum (Durhman et al., 2007; Emilsson, 2008; Getter et al., 2009) and 'John Creech' sedum (Getter and Rowe, 2009) to be fast-growing species that dominated experimental plots.

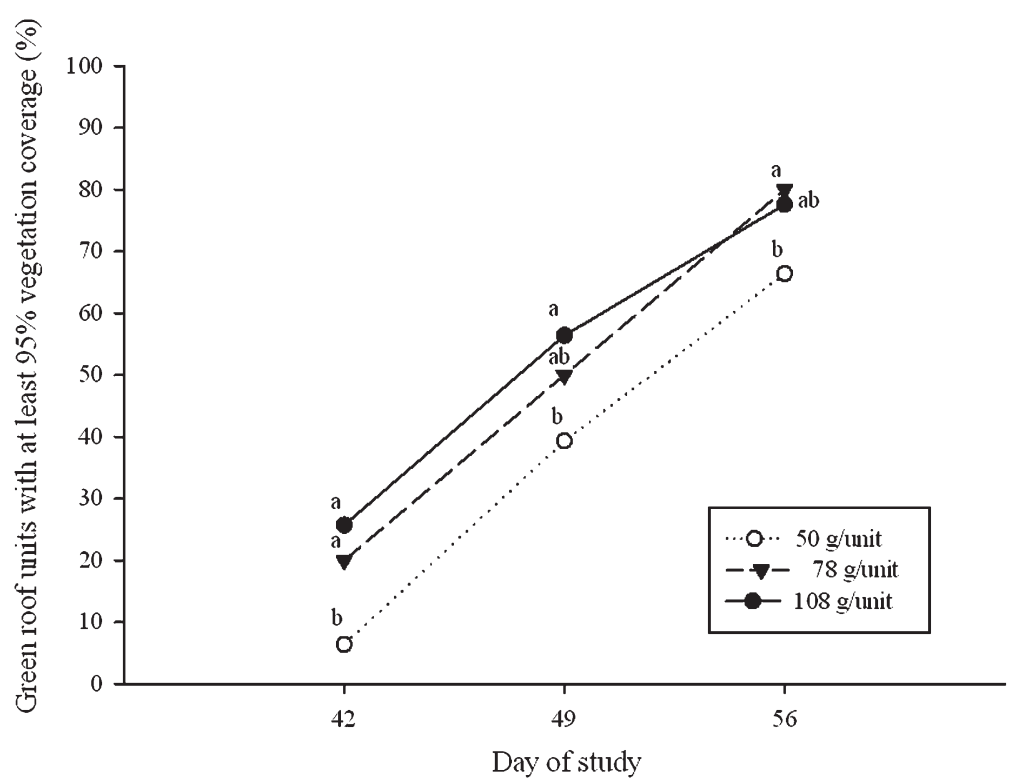

Fig. 1. Percent of single-species and combination species sedum green roof units with at least $95 \%$ vegetation coverage based on visual observation at days 42,49 , and $56(n=140)$. Single-species gray sedum units were excluded, because this species failed to fill units due to slow growth. Differences between fertility levels within day, indicated by different letters, were determined using multiple comparisons for proportions and Tukey's test at $P \leq 0.05 ; 1 \mathrm{~g}=0.0353 \mathrm{oz}$.

Fertilizer has been shown to increase fresh weight of sedums (Fisher and Jauch, 1993); however, in our study, increasing the fertility rate did not produce significant changes in fresh weight for any of the sedum tested.

The balance of species in the finished green roof module was influenced by sedum combination, the starting percent of each species, and fertility rate. For species with similar growth rates we expected that the percent fresh weight per species in the initial combination would be similar to the percent fresh weight per species in the final unit. This result was observed for all combinations of white sedum and 'John Creech' sedum (Table 2), two species with creeping habits and vigorous growth rates. This result was not observed for all combinations of 'Weihenstephaner's Gold' sedum and 'Angelina' sedum, two species that exhibited moderate growth rates. The percent 'Weihenstephaner's Gold' sedum in the finished units was significantly greater than the percent 'Weihenstephaner's Gold' sedum used initially for the $50 \% / 50 \%$ and $25 \% /$ 75\% 'Weihenstephaner's Gold' sedum/ 'Angelina' sedum combinations at the high fertility rate. This was also found for the 25\%/75\% 'Weihenstephaner's
Table 1. Fresh weight at time of harvest for single-species sedum green roof units overall fertility rates $(n=30)$.

\begin{tabular}{lc}
\hline Sedum species & $\begin{array}{c}\text { Fresh } \\
\mathbf{w t}(\mathbf{l b})^{\mathbf{z}}\end{array}$ \\
\hline 'Angelina' sedum & $0.8 \mathrm{c}^{\mathrm{y}}$ \\
Gray sedum & $0.2 \mathrm{~d}$ \\
'John Creech' sedum & $1.5 \mathrm{a}$ \\
Tasteless sedum & $0.7 \mathrm{c}$ \\
'Weihenstephaner's & $0.7 \mathrm{c}$ \\
$\quad$ Gold' sedum & \\
White sedum & $1.0 \mathrm{~b}$ \\
\hline${ }^{2} 1 \mathrm{lb}=0.4536 \mathrm{~kg}$. \\
'Mean separation according to Fisher's least signifi- \\
cant difference test at $P \leq 0.05$ is denoted by different \\
letters.
\end{tabular}

Gold' sedum/'Angelina' sedum combination at the medium fertility rate. These results indicate that when 'Weihenstephaner's Gold' sedum and 'Angelina' sedum are paired together at medium to high fertility rates, 'Weihenstephaner's Gold' sedum will colonize units faster than 'Angelina' sedum even though these two species have similar growth rates when grown as a monoculture (Table 1).

The enhanced ability of 'Weihenstephaner's Gold' sedum to colonize has a more pronounced effect on the finished module appearance than that indicated by the 
Table 2. Percent of total fresh weight for species one [white sedum (WS), gray sedum (GS), 'Weihenstephaner's Gold' sedum (WG)] of each sedum combination and initial proportion of cuttings per fertility rate $(n=10)$.

\begin{tabular}{lccc}
\hline & \multicolumn{3}{c}{ Species one fresh wt (\% total) } \\
\cline { 2 - 4 } Sedum combination and initial & \multicolumn{2}{c}{ Fertility rate $(\mathrm{g} / \text { green roof unit })^{\mathrm{z}}$} \\
\cline { 2 - 4 } proportion of cuttings & $\mathbf{5 0}$ & $7 \mathbf{8}$ & $\mathbf{1 0 8}$ \\
\hline $75 \% \mathrm{WS}+25 \% \mathrm{JC}^{\mathrm{y}}$ & 73.0 & 80.4 & 79.1 \\
$50 \% \mathrm{WS}+50 \% \mathrm{JC}$ & 54.4 & 54.6 & 51.0 \\
$25 \% \mathrm{WS}+75 \% \mathrm{JC}$ & 25.0 & 25.6 & 26.5 \\
$75 \% \mathrm{GS}+25 \% \mathrm{TS}$ & $16.9^{*}$ & $15.4^{*}$ & $11.1^{*}$ \\
$50 \% \mathrm{GS}+50 \% \mathrm{TS}$ & $7.8^{*}$ & $5.7^{*}$ & $7.1^{*}$ \\
$25 \% \mathrm{GS}+75 \% \mathrm{TS}$ & $2.7^{*}$ & $1.8^{*}$ & $1.7^{*}$ \\
$75 \% \mathrm{WG}+25 \% \mathrm{AN}$ & 75.0 & 78.7 & 78.8 \\
$50 \% \mathrm{WG}+50 \% \mathrm{AN}$ & 51.7 & 56.5 & $60.8^{*}$ \\
$25 \% \mathrm{WG}+75 \% \mathrm{AN}$ & 32.0 & $35.2^{*}$ & $37.9^{*}$ \\
\hline
\end{tabular}

${ }^{\mathrm{z}} 1 \mathrm{~g}=0.0353 \mathrm{oz}$.

'JC = 'John Creech' sedum, TS = tasteless sedum, AN = 'Angelina' sedum.

${ }^{*}$ Chi-square test significant at $P \leq 0.05$.

Table 3. Percent cover of 'Weihenstephaner's Gold' sedum (WG) in combination WG/'Angelina' sedum (AN) green roof units as determined by digital image analysis for three fertility rates $(n=5)$.

\begin{tabular}{|c|c|c|c|}
\hline \multirow[b]{3}{*}{ Treatment } & \multicolumn{3}{|c|}{ Cover of WG (\%) } \\
\hline & \multicolumn{3}{|c|}{ Fertility rate $(\mathrm{g} / \text { green roof unit })^{\mathrm{z}}$} \\
\hline & 50 & 78 & 108 \\
\hline $75 \% \mathrm{WG}+25 \% \mathrm{AN}$ & $92.1 \mathrm{a}^{\mathrm{y}}$ & $95.2 \mathrm{a}$ & $94.0 \mathrm{a}$ \\
\hline $50 \% \mathrm{WG}+50 \% \mathrm{AN}$ & $78.5 \mathrm{~b}$ & $86.8 \mathrm{a}$ & $89.8 \mathrm{a}$ \\
\hline $25 \% \mathrm{WG}+75 \% \mathrm{AN}$ & $69.1 \mathrm{~b}$ & $73.5 \mathrm{ab}$ & $76.0 \mathrm{a}$ \\
\hline
\end{tabular}

${ }^{\mathrm{z}} \mathrm{l} \mathrm{g}=0.0353 \mathrm{oz}$.

'Mean separation within rows according to Fisher's least significant difference test at $P \leq 0.05$ denoted by different letters.

fresh weight data alone. DIA showed that the percent visual coverage of 'Weihenstephaner's Gold' sedum in the final unit was substantially greater than the percent visual coverage of 'Angelina' sedum for all 'Weihenstephaner's Gold' sedum/ 'Angelina' sedum combinations at all fertility rates (Table 3 ). More fertilizer increased the percent visual coverage of 'Weihenstephaner's Gold' sedum in finished units for the 50\% 'Weihenstephaner's Gold' sedum and 25\% 'Weihenstephaner's Gold' sedum combination treatments. Fresh weight data for the 25\% 'Weihenstephaner's Gold' sedum combination treatment indicated there was $\approx 10 \%$ more 'Weihenstephaner's Gold' sedum in the finished unit than the starting unit (Table 2). Visual coverage data for the same treatment showed that finished units were $70 \%$ to $75 \%$ covered with 'Weihenstephaner's Gold' sedum (Table 3). This discrepancy may be due to differences in habit between the upright growing 'Angelina' sedum and the spreading 'Weihenstephaner's Gold' sedum. After rooting, 'Angelina' sedum tends to grow vertically initially resulting in a significant amount of fresh weight that does not translate into visual coverage over a unit. Bousselot et al. (2010) found that upright growing plant species show a lower correlation between biomass and DIA as we observed with the more upright 'Angelina' sedum. Getter and Rowe (2009) found that 'Angelina' sedum, due to its erect growth habit, was underrepresented in point frame sampling analysis in plant community experiments. Our findings suggest that starting amounts of 'Weihenstephaner's Gold' sedum will have to be adjusted to achieve a finished product with a desired percent cover. Growers will need to apply substantially fewer 'Weihenstephaner's Gold' sedum cuttings than their target percent cover. Similarly, growers will need to apply substantially more 'Angelina' sedum cuttings to achieve a desired percent cover.

In the gray sedum/tasteless sedum combination units, gray sedum was barely noticeable in the $25 \%$ gray sedum units and only slightly noticeable in the $50 \%$ gray sedum units at time of harvest (Table 2). Tasteless sedum has a spreading habit and grew substantially more vigorously than the rosette-forming gray sedum. Growers must use large starting percentages of gray sedum for this species to have a visual impact in modules. Alternatively, growers should consider using rooted plugs of gray sedum, instead of unrooted cuttings, since rooted plugs will establish in units more quickly and, therefore, have a better chance of surviving long term.

\section{Conclusion}

Based on this study, we would recommend that growers use the medium rate of fertilizer to obtain the maximum number of units with at least $95 \%$ vegetation coverage in the shortest time. The high fertility rate will produce a similar result but at this rate some Sedum species may melt out in warm years. In addition, the medium rate will result in fertilizer cost savings and produce the same or better quality modules. Modules in this study were not tested for performance on rooftops following production; however, we expect modules that received the medium rate will perform well. This research reveals that combining sedums with different growth habits can produce unknown results, but it is possible to predict the appearance of the finished product provided data are available that documents competitive growth patterns. When trying to achieve certain final Sedum species proportions, both in fresh weight and in visual cover, growers may need to adjust the ratios of cuttings.

\section{Literature cited}

Beattie, D.J. and R. Berghage. 2004. Green roof media characteristics: The basics. Proc. 2nd North Amer. Green Roof Conf.: Greening rooftops for sustainable communities. Cardinal Group, Toronto. p. 411-416.

Bousselot, J.M., J.E. Klett, and R.D. Koski. 2010. Extensive green roof species evaluations using digital image analysis. HortScience 45:1288-1292.

Durhman, A.K., D.B. Rowe, and C.L. Rugh. 2006. Effect of watering regimen on chlorophyll fluorescence and growth of selected green roof plant taxa. HortScience 41:1623-1628.

Durhman, A.K., D.B. Rowe, and C.L. Rugh. 2007. Effect of substrate depth 


\section{Research Reports}

on initial growth, coverage and survival of 25 succulent green roof plant taxa. HortScience 42:588-595.

Emilsson, T. 2008. Vegetation development on extensive vegetated green roofs: Influence of substrate composition, establishment method and species mix. Ecol. Eng. 33:265-277.

Emilsson, T., J.C. Berndtsson, J.E. Mattsson, and K. Rolf. 2007. Effect of using conventional and controlled release fertilizer on nutrient runoff from various vegetated roof systems. Ecol. Eng. 29:260-271.

Fisher, P. and M. Jauch. 1993. Duengen beim Ausbringen von Sedum-sprossen. Deutscher Gartenbau 47:316-321.

Getter, K.L. and D.B. Rowe. 2006. The role of extensive green roofs in sustainable development. HortScience 41:12761285.

Getter, K.L. and D.B. Rowe. 2009. Substrate depth influences Sedum plant community on a green roof. HortScience 44 : 401-407.

Getter, K.L., D.B. Rowe, and B.M. Cregg. 2009. Solar radiation intensity influences extensive green roof plant communities. Urban For. Urban Green. 8: 269-281.

Jauch, M. 1993. Die fetten sind nicht fit genug. Deutscher Gartenbau 47:36-37.

Nagase, A. and N. Dunnett. 2011. The relationship between percentage of organic matter in substrate and plant growth in extensive green roofs. Landsc. Urban Plan. 103:230-236.
Rowe, D.B., M.A. Monterusso, and C.L. Rugh. 2006. Assessment of heatexpanded slate and fertility requirements in green roof substrates. HortTechnology $16: 471-477$.

Snodgrass, E.D. and L.L. Snodgrass. 2006. Green roof plants: A resource and planting guide. Timber Press, Portland, OR.

Wark, C.G. and W.W. Wark. 2003. Green roof specifications and standards. Construction Specifier 56(8):1-12.

Williams, R.H. and W.G. LeBlanc. 1995. Pairwise comparisons among proportions. Educ. Psychol. Meas. 55:445-447.

Wolf, D. and J.T. Lundholm. 2008. Water uptake in green roof microcosms: Effects of plant species and water availability. Ecol. Eng. 33:179-186. 